Article

\title{
Leveraging VGI Integrated with 3D Spatial Technology to Support Urban Intensification in Melbourne, Australia
}

\author{
Soheil Sabri *, Abbas Rajabifard, Serene Ho, Sam Amirebrahimi and lan Bishop \\ Centre for SDIs and Land Administration, Department of Infrastructure Engineering, The University of Melbourne, \\ Parkville, VIC 3010, Australia; E-Mails: soheil.sabri@unimelb.edu.au (S.S.), abbas.r@unimelb.edu.au (A.R.), \\ sereneh@unimelb.edu.au (S.H.), amis@unimelb.edu.au (S.A.), i.bishop@unimelb.edu.au (I.B.) \\ * Corresponding author
}

Submitted: 11 March 2016 | Accepted: 17 May 2016 | Published: 15 June 2016

\begin{abstract}
High density residential development in metropolitan Melbourne, where contradictory imperatives of neighbourhood character and urban intensification play important roles, remains an uncertain practice. One key issue for plan implementation is the lack of consistency between authorities, developers and the community in interpreting the standards, design guidelines, and state/local strategies, especially those relating to neighbourhood character. There is currently no mechanism to incorporate community perceptions and place experiences as subjective aspects of neighbourhood character in development assessments. There is also little use of micro-scale and multi-dimensional spatial analysis to integrate these subjective aspects with objective measures (e.g. building volume and height; streetscape) to communicate effectively-and in a limited timeframe-with all stakeholders. This paper explores the potential of two emerging geospatial technologies that can be leveraged to respond to these problems. Evidence in the literature suggests that volunteered geographic information (VGI) can provide community input around subjective aspects of the urban environment. In addition, a deluge of three-dimensional (3D) spatial information (e.g. 3D city models) is increasingly available for micro-level (building- or property-level) assessment of the physical aspects of the urban environment. This paper formulates and discusses a conceptual framework to link these two spatial technological advancements in a virtual geographic environment (VGE) that accounts for micro-scale 3D spatial analysis incorporating both subjective and objective aspects of neighbourhood character relevant in implementing compact city strategies.
\end{abstract}

\section{Keywords}

3D city models; compact city; Melbourne; neighbourhood character; VGE; VGI

\section{Issue}

This article is part of the issue "Volunteered Geographic Information and the City", edited by Andrew Hudson-Smith (University College London, UK), Choon-Piew Pow (National University of Singapore, Singapore), Jin-Kyu Jung (University of Washington, USA) and Wen Lin (Newcastle University, UK).

(C) 2016 by the authors; licensee Cogitatio (Lisbon, Portugal). This article is licensed under a Creative Commons Attribution 4.0 International License (CC BY).

\section{Introduction}

Planning is often emotionally and politically charged. This is nowhere more evident than in the push towards compact cities, where policy imperatives supporting urban intensification often conflicts with community desire to retain neighbourhood character and preserve a sense of identity (Davison, 2011). The neighbourhood is often a battleground, where community perceptions and desires around neighbourhood character drive opposition to development. This "NIMBY" (Not In My Backyard) attitude has both rational and emotional aspects and is common in confrontations between municipal governments, developers and communities (Gilmour, 2012).

Despite its significance in planning, it remains difficult to categorically define neighbourhood character because it is individually experienced, socially variable, 
and changes over time (Dovey \& Woodcock, 2011). These attributes make it challenging to define appropriate indices that can be used in urban analytics to assess neighbourhood character to inform urban planning. There are also consequences for effective communication and engagement with the publicWoodcock, Dovey and Davison (2012) found that public opinion around development is often built on an unclear understanding of the nature and reality of development impacts.

In Australia, urban intensification has become a planning priority, particularly in metropolitan Melbourne which is the country's fastest growing city and projected to be its largest by 2030 (Victoria Government, 2014). Urban intensification seeks to cluster higher density housing around activity centres to leverage existing facilities and infrastructure: agglomerating effects are expected to attract more services, employment and facilities. The state planning system, which takes into consideration physical, social and economic aspects of the urban environment, has formalised neighbour character as a primary criterion in urban residential development. However, there is a tendency for municipal governments to implement this concept locally using objective (measurable, visible, tangible)albeit at times simplistic-indicators such as style of construction, roof types, driveways, fencing, spatial patterns, height limits, etc.

These do not fully capture the essence of neighbourhood character. Conflicting perceptions around what constitutes 'character' and poor definition of those aspects of character under threat continue to be a central theme in community opposition to residential development aimed at urban intensification (Schwartz, Dodd, \& Haley, 2014). In part, it is believed that the strength of emotion in such opposition stems from a general lack of tradition in higher density living in Australia and the desire to preserve the suburban norm of a "quarter acre block". The lack of clarity and consistency around neighbourhood character is further evident when parties pursue adjudication in the Victorian Civil and Administrative Tribunal (VCAT): it has been shown that the Tribunal tends to interpret planning schemes in an altogether different way than the council intended (Victorian Planning Reports, 2013).

Two clear issues emerge. Firstly, the prevalence of objective indicators in defining neighbourhood character ignores subjective (not measurable, not visible and not tangible) aspects of the urban environment such as sense of place and neighbourhood identity (de Jong, Fuller, \& Gray, 2013). This limits the ability of planners and developers to fully consider the interaction between objective and subjective aspects in asserting neighbourhood character. Secondly, guidelines for higher density urban residential development require not only more information about the subjective as- pects of the urban environment, but also greater integration of both objective and subjective elements. The ongoing frequency of opposition provides evidence that interpretation and application of urban residential development requirements still does not adequately reflect community perceptions of neighbourhood character (Dovey, Woodcock, \& Wood, 2009a). In addition, a lack of consistency in interpretation between authorities, developers and the community further underscores the need to improve information inputs into development assessment to achieve broader priorities in urban intensification.

In response, this paper explores the potential of two emerging geospatial technologies that can be leveraged to respond to the problematic representation and evaluation of neighbourhood character in the context of higher-density development in Victoria. Evidence in the literature suggests that volunteered geographic information (VGI) can provide community input around subjective aspects of the urban environment (Harvey \& Aultman-Hall, 2015). In addition, a deluge of three-dimensional (3D) spatial information (e.g. 3D city models and Building Information Models) is being increasingly utilised for micro-level (buildingor property-level) assessment of physical aspects of urban environment such as shadow casting (Rafiee, Dias, Fruijtier, \& Scholten, 2014), sky view factor analysis (Chen et al., 2012), and noise management (Herman \& Rezník, 2013). 3D models can also deliver better representation and communication of real world features in an interactive virtual environment for clearer understanding of proposals by the community (Lin et al., 2013; Smith, Bishop, Williams, \& Ford, 2012). Although a combination of these two inter-linked technologies can potentially satisfy the requirements of plan implementation, there has hitherto been little consideration of a formal mechanism for linking VGI and 3D spatial information in support of sustainable urban intensification.

This paper argues that a new framework that better represents and measure the subjective and objective aspects of neighbourhood character is required, particularly in the case of compact cities that are becoming vertically extended and in which complex physical, functional, and contextual relationships exist. To develop this framework, the paper first provides a background on key issues in plan implementation, specifically in Victoria. The relationship between planning and technology is then reviewed as a precursor to introducing emergent technologies that impact planning. Based on this review of the literature, a conceptual framework to enable a more holistic approach to plan implementation in compact cities that accounts for both objective and subjective aspects of the urban environment is developed. Finally, the paper concludes with a discussion about the potential opportunities and challenges of using this framework in future work. 


\section{Background}

\subsection{Neighbourhood Character: Objective vs. Subjective Indicators}

Although it receives significant attention within the planning literature, the concept of place identity-or neighbourhood character-remains difficult to define precisely and consistently because it interfaces with planning, politics and social sciences (Hague, 2005). Relph (1976) emphasised the importance of understanding the significance that places have to people and this, he argued, was based on their identification of, and with, a place. This comprised three components: physical characteristics, experiences local to the setting and meaning derived through people's experiences in the physical setting. This interplay between physical, social and psychological factors as constituting the elemental definition of place character recurs throughout planning literature (e.g. Sepe \& Pitt, 2014) and is best illustrated in Montgomery's (1998) conceptualisation of place (Figure 1).

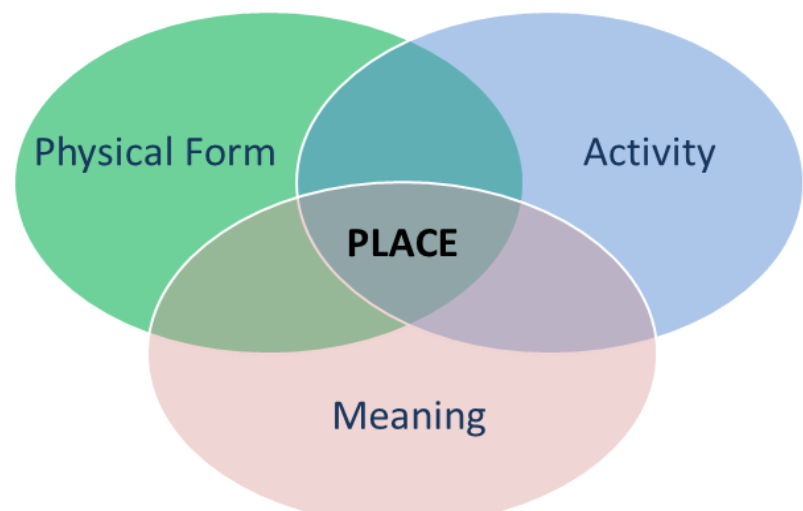

Figure 1. Montgomery's concept of place (Montgomery, 1998).

Dovey et al. (2009a) described neighbourhood character as a function of urban typology, density and street life. The authors found three key determinants: residents' experience of the place, socio-cultural outcome of urban form, and the formal spatial structure and urban morphology. This view takes into consideration the "multiplicities" and "assemblages" of residents and incorporates both subjectivities (e.g. feeling of the place, experience, socio-cultural flavour) and objectivities (e.g. building and neighbourhood form, physical and environmental aspects, streetscape). However, at times, it can be difficult to make a clear distinction between subjective and objective indicators.

The objective aspects of neighbourhood character are better understood, measured and communicated with local communities by urban practitioners and researchers (Sabri, Pettit, Bishop, \& Rajabifard, 2015). These aspects can be categorised into spatial and functional indicators: building volumes, height, and density are examples of spatial indicators, and land use type, diversity, and accessibility provide functional indicators. Given that these indicators are quantitative and easily measurable (Larco, 2015), most regulatory guidelines and practical reports by governments use a range of objective indicator to measure the qualitative aspects of neighbourhood character. For instance, the Western Australian Ministry for Planning have developed urban fabric indicators (Porta \& Renne, 2005) to ensure the liveability of neighbourhoods. These include land use diversity, street connectivity, number of buildings and number of lots (Table 1 ).

Although the physical environment contributes significantly to a sense of place (Stedman, 2003), social construction and place experience are other factors that need to be taken into consideration. These factors constitute the subjective aspects of neighbourhood character but have been neglected in most regulative guidelines pertaining to neighbourhood character and sustainability of urban design (Ewing, Hajrasouliha, Neckerman, Purciel-Hill, \& Greene, 2015; Porta \& Renne, 2005; Purciel et al., 2009).

Subjective indicators include social interactionstheir type and the intensity of these activities through time, e.g. daily, weekly, and monthly (Bonaiuto, Fornara, Ariccio, Cancellieri, \& Rahimi, 2015; Kropf, 1996; Walton, Murray, \& Thomas, 2008). Other socially constructed aspects which feature in the literature as subjective indicators include people's interpretation and experience of places including positive and negative views on physical and natural features of neighbourhood (Green, 1999, 2010; Jive'n \& Larkham, 2003) (Table 1). In some cases such indicators contribute significantly to constructing a sense of place independent of physical qualities embodied in the setting (Kyle \& Chick, 2007). In a study of Subiaco city in Western Australia, Davison and Rowden (2012) found that residents gave equal significance to the social and experiential meaning of places as they did to physical form and appearances of streets. These subjective aspects of neighbourhood character are regarded as key factors underlying residents' resistance to urban intensification strategies and projects (Davison \& Rowden, 2012; Dovey et al., 2009a; Kyttä, Broberg, Tzoulas, \& Snabb, 2013; Vallance, Perkins, \& Moore, 2005).

Studies have shown that the measurement of objective aspects of neighbourhood character, particularly with the application of spatial technologies, is a straightforward process (Ewing et al., 2015). Subjective aspects however, have tended to be measured indirectly using physical indicators. For instance, Harvey et al. (2015) suggested "streetscape skeleton" design variables that can be efficiently measured using geospatial information, as the sense of safety and social functionality of urban spaces at the spatial resolution of city blocks. They measured seven skeleton design variables for each streetscape including width, length, height, 
Table 1. Objective and subjective indicators of neighbourhood character as derived from the literature.

\begin{tabular}{|c|c|c|c|}
\hline Aspects & Category & Indicators & Authors \\
\hline \multirow[t]{7}{*}{ Objective } & Physical & $\begin{array}{l}\text { Building volumes, density, and } \\
\text { aesthetics }\end{array}$ & $\begin{array}{l}\text { Bonaiuto, Fornara and Bonnes (2006); } \\
\text { Bonaiuto et al. (2015); Porta and Renne } \\
\text { (2005); Walton et al. (2008) }\end{array}$ \\
\hline & & Green areas quantity and quality & $\begin{array}{l}\text { Green (2010); Stock, Bishop and Green } \\
\text { (2007); Glaesener and Caruso (2015); Hunter } \\
\text { and Brown (2012) }\end{array}$ \\
\hline & & $\begin{array}{l}\text { Streetscape, tree canopy, width, } \\
\text { urban furniture, }\end{array}$ & $\begin{array}{l}\text { Ewing et al. (2015); Harvey, Aultman-Hall, } \\
\text { Hurley and Troy (2015); Harvey and Aultman- } \\
\text { Hall (2015); Hunter and Brown (2012); Porta } \\
\text { and Renne (2005) }\end{array}$ \\
\hline & & $\begin{array}{l}\text { Building facade, private open spaces } \\
\text { and setbacks, fences }\end{array}$ & $\begin{array}{l}\text { Ewing et al. (2015); Porta and Renne (2005); } \\
\text { Purciel et al. (2009); Victoria Government } \\
\text { (2015) }\end{array}$ \\
\hline & Functional & Land use types and diversity & $\begin{array}{l}\text { Glaesener and Caruso (2015); Schwarz (2010); } \\
\text { Verburg, de Nijs, van Eck, Visser and de Jong } \\
\text { (2004) }\end{array}$ \\
\hline & & $\begin{array}{l}\text { Accessibility to urban services (e.g. } \\
\text { education, health, and recreation) }\end{array}$ & $\begin{array}{l}\text { Walker, Block and Kawachi (2013); Xiao, } \\
\text { Orford and Webster (2015) }\end{array}$ \\
\hline & & $\begin{array}{l}\text { Street network pattern and } \\
\text { connectivity }\end{array}$ & $\begin{array}{l}\text { Brownson, Hoehner, Day, Forsyth and Sallis } \\
\text { (2009); Dovey and Wood (2014); Fenton } \\
\text { (2012); Porta and Renne (2005) }\end{array}$ \\
\hline \multirow[t]{4}{*}{ Subjective } & $\begin{array}{l}\text { Social } \\
\text { Construction }\end{array}$ & Sociability, security, safety & $\begin{array}{l}\text { Green (2010); Kyle and Chick (2007); Stedman } \\
\text { (2003) }\end{array}$ \\
\hline & & Socio-cultural activities & $\begin{array}{l}\text { Bonaiuto et al. (2006); Foth, Bajracharya, } \\
\text { Brown and Hearn (2009); Smith and Phillips } \\
\text { (2001) }\end{array}$ \\
\hline & Experiential & $\begin{array}{l}\text { Place attachment, cultural significant } \\
\text { elements }\end{array}$ & Chang (2000); Jean (2015); Stedman (2003) \\
\hline & & $\begin{array}{l}\text { Place satisfaction, microclimate, } \\
\text { equitable access to services }\end{array}$ & $\begin{array}{l}\text { Bonaiuto et al. (2015); Fleury-Bahi, Félonneau } \\
\text { and Marchand (2008); Qin, Zhou, Sun, Leng } \\
\text { and Lian (2013) }\end{array}$ \\
\hline
\end{tabular}

cross-sectional proportion, street wall continuity, buildings per length, and tree canopy coverage as an indirect measure of neighbourhood subjective aspects.

Other studies have also utilised relatively similar physical indicators for indirect measurement of subjective aspects of neighbourhood character. These include sky exposure (Samuels, 2002, p. 695), facade continuity (Meehan, 1982, p.438), softness (e.g. easement gardens indicating transparency and transitional space) (Hunter \& Brown, 2012, p. 408), visual complexity, number of buildings, sedibility (measuring the number of seating opportunities) and detractors (blank walls, traffic signs, large dumpsters) (Porta \& Renne, 2005, pp. 5-11). The reason for not being able to directly measure subjective aspects of neighbourhood character is stated as being the limited sample size used in audit based urban design and community perception measurement (Harvey et al., 2015). Often not enough is known about the relationship between these indictors-either singly or in combination-and people's subjective responses to them. This potentially explains why regulatory guidelines for neighbourhood character assessment by municipal governments consistently overlook subjective indicators.

\subsection{The Concept of Neighbourhood Character in Victoria's Planning System}

In Victoria, neighbourhood character is a primary concern in planning. The government's definition of neighbourhood character is consistent with the literature to date, mandating that developments consider both objective and subjective elements and their combined relationships. However, their description of neighbourhood character is of very little assistance to planners:

\footnotetext{
"Neighbourhood character is essentially the combination of the public and private realms. Every property, public place or piece of infrastructure makes a contribution, whether great or small. It is the cumulative impact of all these contributions that estab-
} 
lishes neighbourhood character. The key to understanding character is being able to describe how the features of an area come together to give that area its own particular character. Breaking up character into discrete features and characteristics misses out on the relationships between these features and characteristics. Understanding how these relationships physically appear on the ground is usually the most important aspect in establishing the character of the area." (Victoria Government, 2015)

Lack of clarity continues in the residential design code, ResCode, where neighbourhood character is used as the starting point for assessing all residential development applications, but only applies to developments up to three storeys in height. Guidelines for higher density residential developments, while continuing to refer to neighbourhood character, also demand design responses that integrate physical, social and economic aspects of the urban environment as well as consideration of the strategic prospects of the area. The issue of neighbourhood character is specifically addressed by the Neighbourhood Character Overlay (Victoria Government, 2015, section 43.05), which aims to:

- Identify areas of existing or preferred neighbourhood character;

- Ensure that development respects the neighbourhood character;

- Prevent, where necessary, the removal of buildings and vegetation before the neighbourhood character features of the site and the new development have been evaluated.

These objectives are then implemented independently by each of the state's 79 local municipal governments, who develop their own Local Planning Policy Framework (including a Municipal Strategic Statement and other local planning policies). Municipal governments must provide a schedule that contains a statement of the key features of neighbourhood character and the neighbourhood character objectives to be achieved in any affected area. However, municipal planners often describe neighbourhood character by referencing physical and functional elements of the urban environment. These include topography, street block length, landscaping and vegetation in the neighbourhood, diversity of housing, building mass and height, architecture and roof styles, street trees, and waterways (Victoria Government, 2015). These indicators do not describe the subjective aspects of neighbourhood character, such as "sense of place and community meaning".

Table 2 provides an example of a neighbourhood character description as developed for the Ringwood Activity Centre. Ringwood has been prioritised by the state government in its vision for achieving growth and has been designated as a Metropolitan Activity Centre-the highest priority centres outside of the CBD. This is an example of urban intensification policies at work. The table shows how neighbourhood character has been defined by physical elements and this conceptualisation is perpetuated by objectives that developers need to meet in proposed designs. In this instance, architectural styling, dwelling type (number of storeys) and design, construction materials, type of landscaping and even location of driveways are all used to identify elements of existing neighbourhood character. This does not change radically in the statement about future character and how this will be achievedstill relying on objective elements like building form and height as neighbourhood character objectives in design and development.

Further support of this bias towards using objective indicators can be seen in Dovey et al. (2009a). The authors found that despite the emphasis placed on neighbourhood character in planning, Victorian residents' perspectives pertaining to character were reflected only to a limited extent in regulations. Drawing on an intensive range of interviews and evidence (Dovey, Woodcock, \& Wood, 2009b), the authors found that in Melbourne's inner-suburbs, when the term 'character' was raised in urban development debate, the views of stakeholders - the community, developers, politicians, and planners-tended to diverge significantly. Potentially, this could be due to a naïve image of the spatial, social, and economic impacts of urban intensification projects (Woodcock, Dovey, Wollan, \& Beyerle, 2010). It remains unclear how residents' experience of their neighbourhoods can be measured and incorporated by planners and decision makers.

From the literature and contextual examples provided above, it is evident that implementation of planning policies to meet policy imperatives on urban intensification, which also attend to neighbourhood character, requires localised assessment (D'Argent, Beringer, Tapper, \& Coutts, 2012; Victoria Government, 2014). Despite emerging opportunities, planners and developers still depend on paper-based information as a means of engaging with the community, disregarding readily available ICT and spatial technology applications (Houghton, Miller, \& Foth, 2014). Such engagement is also limited by truncated decision-making-in Victoria, public notice periods are determined by municipal authorities although the norm is to advertise for two weeks (Victoria Government, 2014). Consequently, current planning mechanisms are severely limited in their ability to fully accommodate and consider communities' subjective perceptions of their environment. The basis for engagement and analysis is therefore fundamentally flawed (Woodcock et al., 2010). 
Table 2. Neighbourhood character statement and objectives for Ringwood Activity Centre (Maroondah City Council).

\begin{tabular}{|c|c|c|}
\hline Existing Character Elements & Preferred Future Character & Achieved By \\
\hline $\begin{array}{l}\text { - Architectural styles include simple } \\
\text { Post War era 1950s and 1960s } \\
\text { weatherboard and brick, } 1960 \text { s and } \\
1970 \text { s-shaped and } 1980 \text { s } \\
\text { adaptations of the L-shaped form. } \\
\text { - } \text { Dwellings are generally single storey } \\
\text { and offset to one side of the lot to } \\
\text { provide a driveway down one side. } \\
\text { - Materials are mixed brick and } \\
\text { weatherboard with tiled, pitched } \\
\text { roofs. } \\
\text { - Lot sizes vary, but are generally 500- } \\
\text { 1200m², with occasional smaller and } \\
\text { larger blocks. } \\
\text { - Established gardens are common } \\
\text { throughout, frequently with canopy } \\
\text { trees as features. } \\
\text { - Multi-unit sites have been developed } \\
\text { with dwellings aligned along the side } \\
\text { boundary and a driveway to one } \\
\text { side. } \\
\text { - Generally single dwellings front the } \\
\text { street, while multi-unit development } \\
\text { generally front side boundaries. } \\
\text { - Dwelling design is conventional, } \\
\text { pitched roof, brick veneer, or in some } \\
\text { instances timber, } 2 \text { to } 3 \text { bedrooms } \\
\text { and garage. } \\
\text { - Street trees are well established. }\end{array}$ & $\begin{array}{l}\text { - Intent: Foster increased } \\
\text { residential densities in } \\
\text { preferred residential } \\
\text { development precincts and to } \\
\text { establish multi-level, multi- } \\
\text { occupancy apartment style } \\
\text { buildings as the preferred } \\
\text { form of dwelling design and } \\
\text { neighbourhood character. } \\
\text { - The preferred neighbourhood } \\
\text { character will provide for } \\
\text { multi-level, apartment-style } \\
\text { residential buildings that } \\
\text { retain elements of the existing } \\
\text { garden setting. Buildings will } \\
\text { be larger apartment style, } \\
\text { single buildings constructed } \\
\text { on consolidated sites. } \\
\text { - New development will provide } \\
\text { for a higher intensity of site } \\
\text { development than occurs at } \\
\text { present. } \\
\text { - New development will } \\
\text { recognise the existing street } \\
\text { pattern and create buildings } \\
\text { that form visual landmarks } \\
\text { throughout the precincts. }\end{array}$ & $\begin{array}{l}\text { - Constructing multi-level, multi- } \\
\text { occupancy residential buildings. } \\
\text { Consolidating existing lots to create } \\
\text { larger development sites } \\
\text { containing multi-level, multi- } \\
\text { occupancy buildings. } \\
\text { - Providing strategic opportunities } \\
\text { for the planting or retention of } \\
\text { canopy trees to maintain the } \\
\text { existing streetscape and frame } \\
\text { larger buildings. } \\
\text { - Ensuring that the building form } \\
\text { retains a human scale and is } \\
\text { designed to avoid large, block like } \\
\text { structures dominating the } \\
\text { streetscape. } \\
\text { - Providing a mix of building forms } \\
\text { and heights that generally accord } \\
\text { with the Ringwood Activity Centre } \\
\text { indicative building height map. } \\
\text { - Consolidating sites in a logical and } \\
\text { progressive manner that avoids the } \\
\text { creation of isolated lots of limited } \\
\text { redevelopment potential. } \\
\text { - Providing the opportunity to } \\
\text { enhance pedestrian activity and } \\
\text { contribute the creation of a sense } \\
\text { of place. } \\
\text { - Relating building height to lot size. } \\
\text { - Limiting vehicle crossings to } 1 \text { per } \\
\text { site and providing common access } \\
\text { to sites. }\end{array}$ \\
\hline
\end{tabular}

\section{Leveraging New Geospatial Technologies in Planning}

\subsection{D Geospatial Information and Spatial Planning Practices}

Spatial information and technologies have long underpinned planning activities. In response to the limitations identified in the preceding section, we suggest two recent developments in spatial technology that might be effectively harnessed.

3D spatial information plays an important role in accurate communication of future urban developments. During the last two decades, improvements in geospatial data and infrastructure have offered a robust alternative to $3 \mathrm{D}$ architecture models in urban planning and design (Biljecki, Stoter, Ledoux, Zlatanova, \& Çöltekin, 2015; Sabri et al., 2015). 3D city models have vastly improved and now provide a realistic representations through higher levels of detail, and provide users with greater interactivity as well as the abil- ity to query elements of the models (Zhu et al., 2011). These advancements have added more value to sustainable information sharing and semantic representation of volumetric urban objects, such as buildings, vegetation objects, waterbodies, and other urban infrastructures (Amirebrahimi, Rajabifard, Mendis, Ngo, \& Sabri, 2016; Gröger \& Plümer, 2012; Zhu et al., 2011). Other improvements in 3D geospatial information including standardisation of 3D GIS formats such as City Geography Markup Language (CityGML) (Kolbe, Gröger, \& Plümer, 2005), Building Information Models (Mignard \& Nicolle, 2014), and web 3D visualisation (Herman \& Rezník, 2013; Shojaei, Rajabifard, Kalantari, Bishop, \& Aien, 2014; Trubka, Glackin, Lade, \& Pettit, 2015) have all contributed to improving urban planning and management practices. Some examples include urban heating energy demand forecasting (Strzalka, Bogdahn, Coors, \& Eicker, 2011), urban engineering (Borrmann et al., 2014), and future urban development scenario assessment (Trubka et al., 2015).

A recent study by Biljecki et al. (2015) reviewed the 
applications of 3D city models in non-visualisation and visualisation-based use cases. Different analyses and measurements such as classifying building types, and energy demand estimation are categorised in nonvisualisation use cases. Other visualisation-based analyses and facilities like visibility, estimation of shadow cast, noise pollution, urban skyline, estimating population, and communication of urban information to residents are well evaluated in this comprehensive study. The majority of use cases listed in this study focused on physical and functional measurement of building and urban areas.

There are few examples of using 3D city models in a virtual environment to foster urban planning; in particular, measuring the social construction and place experience aspects of the urban environment. This is despite the fact that studies in virtual reality (VR) using 3D graphics have demonstrated the potential of these technologies for measuring subjective aspects such as safety (Toet \& van Schaik, 2012) and people's behaviour and perceptions (Bishop, 2001; Chen \& Bishop, 2011).

Recent literature on spatial information and urban design has also highlighted the necessity of measuring subjective aspects particularly in urban intensification projects, which include socially sensitive and vertical urban growth (Harvey \& Aultman-Hall, 2015; Kytta, Broberg, Haybatollahi, \& Schmidt-Thome, 2015; Schmidt-Thome, Wallin, Laatikainen, Kangasoja, \& Kyttä, 2014). The next section explores the possibility of linking 3D city models with VGI and formulates a conceptualisation that fulfils the requirement of the State of Victoria guidelines and standards on higher density residential building development.

\subsection{Volunteered Geographic Information in Urban Planning}

Since Goodchild (2007) first proposed the term "volunteered geographic information" (VGI), it has come to encompass a broad range of citizen-based (or nonspecialists) activities in the collection of information or data with a geographic attribute. This data is typically uploaded and shared using a Web 2.0 platform that, in itself, engenders participation (Kolbitsch \& Maurer, 2006). Core to its conceptualisation is the context in which VGI is used, which is likely to dictate differing priorities in data quality, credibility, role of participant and participant's relationship with formal agencies (e.g. Budhathoki, Nedovic-Budic, \& Bruce, 2010; Goodchild, 2007; Elwood, 2008). Participants' motivation for contributing to VGI is often discussed in the literature, where a dichotomy between intrinsic (individual desire and needs) and extrinsic (external validation or recognition) factors is often upheld (e.g. Leimeister, Huber, Bretschneider, \& Krcmar, 2009; Zheng, Zha, \& Chua, 2011). In the context of planning, Seltzer and Mahmoudi (2013) argued that the act of invoking citizen participa- tion creates a distinction from more general crowdsourcing activities: the motivation of the participants has lesser impact in crowdsourcing whereas citizen participation is often associated with solicitation of specific input towards planning strategies and scenarios.

Although there is a tendency in the literature to persist with this distinction between crowdsourcing and VGI (to reflect the degree of active participation in data production by lay persons), in this paper, we adopt Haklay's (2013) proposition that crowdsourcing is a type of VGI. Haklay firstly established citizen science as a type of VGI, and within this, defined geographical citizen science as a specific subset where "the collection of location information is an integral part of the activity" (Haklay, 2013, p. 112). This, he argued, justifies the applicability of geographical citizen science in areas with a high population density or high levels of activity within the natural environment (since these are areas less likely to be affected by motivation or environmental conditions that impact upon participation). He then proposed a typology of citizen participation for geographical citizen science that is influenced by power differences between stakeholders that are implicit in any social process - of which urban planning is a prime example (Sieber, 2006). Haklay's spectrum ranged from 'crowdsourcing' (lowest level of participation) to 'extreme citizen science' (highest level of participation in which citizens are integrated with experts in problem definition, data collection and analysis) with levels of participation increasing in line with cognitive engagement, degree of integration among participants and consequently knowledge production.

Therefore, the use of VGI, echoing earlier discourses around participatory GIS (e.g. Elwood \& Leitner, 2003; Weiner, Harris, \& Craig, 2002), is frequently held up as a similar enabler of democratic participation in formal decision-making. We see this reflected in a range of participatory planning activities. Adams (2013) argued that VGI could be integrated with planning processes by facilitating more open channels for receiving public input. Engaging more people will lead to the provision of more useable data that is more representative of stakeholder interests, and extend spatial data resources beyond the limitations imposed by the organisational mandates of formal data producers. Brabham (2009) found that crowdsourcing public participation in planning processes appear undifferentiated from other types of participatory GIS activities up to the point where the crowd becomes engaged in the evaluation and validating of proposed solutions. In addition, there is evidence that there is growing interest from the public in engaging with planning through social media platforms (Evans-Cowley \& Hollander, 2010). Indeed, Foth, Odendaal and Hearn (2007) found that participatory aspects of such platforms provided myriad opportunities for what they termed "urban epistemologies" about the urban environment to emerge. 
The fact that VGI inherently has spatial attributes gives it a high degree of applicability for use in urban planning. Predicated on the concept of citizens-assensors (Goodchild, 2007) and with technological advances, VGI has progressively become more comprehensive and detailed, leading to increasing adoption of this data type in urban applications (Song \& Sun, 2010). In addition, VGI has also been evolving to include more 3D forms of data (Goetz \& Zipf, 2013). In the context of this paper, this evolution is important in terms of public engagement and participation since 3D VGI can be used to support the construction of 3D city models (Goetz \& Zipf, 2013) which more accurately reflect our reality and invite greater identification from the public with proposed developments (Foth et al., 2009). This, Jiang (2013) argued, demonstrates the value of VGI in spatial analytics and computation.

There are numerous instances of 2D and 3D applications of VGI in planning in the literature. Earlier applications include CommunityViz, a GIS-based planning support system that combines 2D ArcView and 3D town building software (Foth et al., 2009). More recently, Goetz and Zipf (2013) used 3D Open Street Map data to construct 3D city models that can be used for planning purposes. In Slovenia, VGI applications are being used to improve urban cycling conditions and public spaces (Nikšič et al., 2014). In her review of 100 mobile planning apps, Ertiö (2013) found many that dealt with urban infrastructure and urban governance. Knudsen and Kahila (2012) found VGI (GPS tracking using smartphones) being applied in Denmark to understand how young people used neighbourhood infrastructure, but also to capture residents' perspectives on the neighbourhood as input into a new master plan. In another study in Finland, the authors also found VGI used to better understand aspects of the urban environment that support social sustainability. Similar applications of VGI to discern or create understanding around the more subjective aspects of spatial planning include "Place, I Care!" (PIC!) (Campagna, Floris, Massa, Girsheva, \& Ivanov, 2015)

Nonetheless, there are disadvantages to using VGI in planning. Partly, this comes back to the issue of participant motivation, which in the context of planning, likely requires willingness to be coincident on two fronts: to contribute to the production of VGI, and to contribute to the planning process (Obermeyer, 2007). However, given Haklay's typology raised above, this argument may be diluted by the fact that crowdsourced data could still be leveraged as a passive input into planning processes. Rydin (2010) also questioned the effectiveness of VGI as a participatory mechanism in planning if engagement is not sustained and relies instead on ephemeral sources of input. Aitamurto, Leiponen and Tee (2011) found that the benefit of VGI can be diluted if the problem presented to the crowd is poorly defined, and subsequently, if feedback to im- prove the fitness of the proposed (VGI-derived) solutions is not given. However, Seltzer and Mahmoudi (2013) argued that posing a well-defined problem to the crowd may well be difficult to execute in planning since the very nature of public participation in planning is to use the public to better identify and define planning goals. In addition, the use of VGI in planning has tended to be framed around applications in strategic planning (Elmadhoun Ahmed, 2010) or urban governance (Ertiö, 2015); there are limited examples of the use of VGI in plan implementation itself.

\section{A Conceptual Model to Support an Integrated Approach to Planning}

To develop a response to the gaps highlighted in existing urban intensification practices in Melbourne, particularly in the plan implementation phase, this section maps the links between VGI, 3D spatial information, and subjective-objective measurement of neighbourhood character. We propose a model enabled by spatial technology that is able to facilitate micro-level analysis. By using semantic and geo-referenced data, the model can potentially enable integration of different types of data to support more effective understanding of community perceptions around current and future neighbourhood character. The model is also likely to produce outcomes that can be analysed and communicated with stakeholders to better support plan implementation.

We further propose that this integrated approach be implemented in a new generation of geographic analysis tool: Virtual Geographic Environments (VGEs) (Lin et al., 2013). VGEs focus on three functionalities: multi-dimensional visualisation, dynamic phenomenon simulation, and public participation-all of which are in line with plan implementation requirements in Melbourne. The ability of VGEs to facilitate model sharing and multi-model integration (Zhang, Chen, Li, Fang, \& Lin, 2016) offers an opportunity for integrating physical-social analysis for urban planning and design purposes; further, VGEs can act as a workspace for multistakeholder-based collaborative planning experiments.

From a technical perspective, the advantages of utilising VGEs to support an integrated modelling and analytical paradigm for urban planners and other stakeholders can be further augmented through the use of other web-based systems. Examples include: semantic integration techniques (e.g. ontology-based spatial urban data development, ontology for planning and design), and developing application programming interfaces (APIs) for data discovery and urban analytical tools and services (Psyllidis, Bozzon, Bocconi, \& Titos Bolivar, 2015). As such, a web ontology browser (WOB) and a web-based user interface can be developed to support discovery, modelling, visualisation and analysis of heterogeneous urban data types (e.g. 
transport, vegetation, housing, energy) for different stakeholders. Through these mechanisms, compatibility and interoperability issues related to different data types, cross-scale analytics, and cross-discipline models can potentially be overcome.

Since a detailed technical explanation of VGEs is not within the scope of this paper, the focus of the rest of this section is on conceptualising the links between spatial information and subjective-objective measurements.

\subsection{Conceptual Links between 3D Spatial Information and Neighbourhood Character}

In the context of this study, micro-level analysis refers to the building envelope, building layout and design, and the streetscape. Design guidelines for higher density residential development in Victoria place significant emphasis on the physical and functional aspects of developments. Physical aspects include interior and exterior building elements such as private and public spaces and landscape design (Figure 2), energy efficiency, the space and layout of car parking, building frontages, and the relationship between street pattern and the size of the building blocks (Department of Sustainability and Environment, 2004). Functional aspects range from promotion of a focus on public transport to greater mix of land uses, while increasing the number of residents.Similar to these guidelines, development standards for medium density developments (up to three storeys), ResCode, are also focused on the micro- evaluation of building development. Overshadowing, overlooking, daylight to existing and new windows are some examples of ResCode standards.

While the application of 3D visualisation and some physical analysis such as overshadowing have been utilised in some development proposals, particularly in Melbourne's CBD (Hassett, 2014), the advantages of using multi-dimensional spatial information are not fully exploited in planning and design practice.

Figure 3 shows the potential application areas of current 3D spatial information, models and analyses in a VGE in response to the physical and functional requirements of medium-rise and high-rise residential development in Melbourne. In addition, the components of analysis and visualisation exhibited in Figure 3 explicitly cover micro-scale spatial analysis and application of 3D spatial technology in the plan implementation phase.

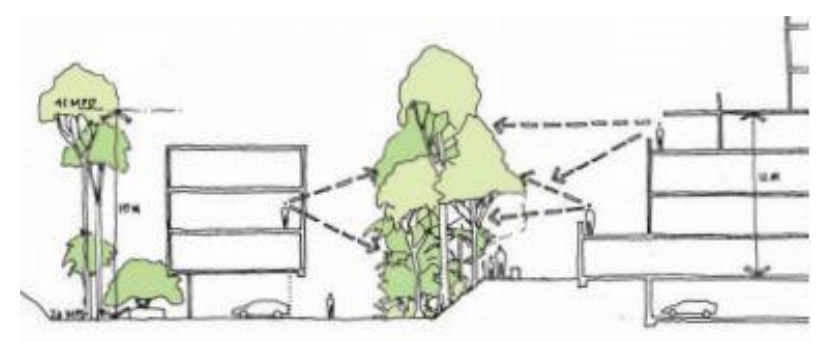

Figure 2. Landscape and outlook evaluation of dwellings. Source: Department of Sustainability and Environment (2004).

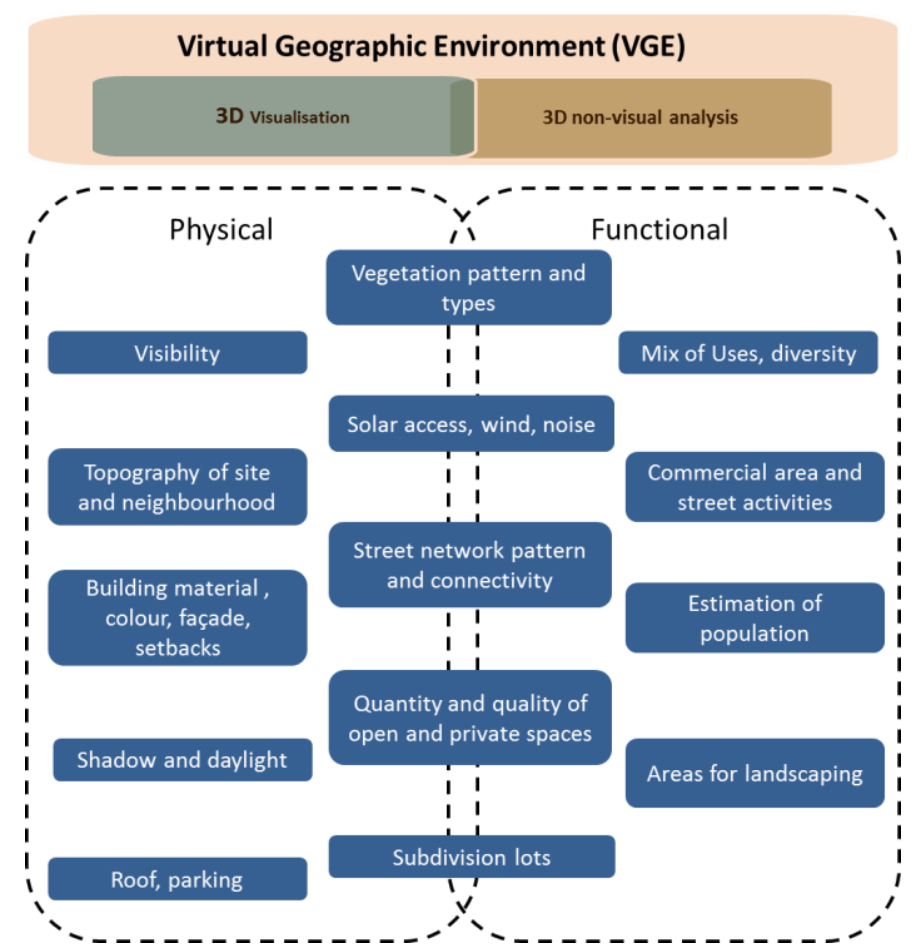

Figure 3. Measuring and visualising objective aspects of building and neighbourhood using 3D spatial technology in a virtual geographic environment. 


\subsection{Conceptual Links between VGI and Neighbourhood Character}

There are two concerns in Victoria's planning system that might hinder an effective incorporation of dynamic community perceptions as the subjective aspect of neighbourhood character in plan implementation. First, the Planning and Environment 1987 Act currently dictates a two-week timeframe for allowing residents to lodge potential objections to development proposals. This process is currently mainly paper-based and has not been framed to leverage digital infrastructures for more effective communication.

Secondly, while state and local governments do communicate with the public to receive input for neighbourhood character studies and to develop guidelines for high rise residential buildings for the purposes of the strategic planning process, this is a one-off process and the community's changing preferences-often a corollary of the transformation of the socio-cultural profile of a neighbourhood-are overlooked. As such, the role of VGI, including 3DVGI, is crucial to provide not only a source of input to measure subjective aspects, but importantly to provide a data source that is sufficiently dynamic to accurately reflect changes within the community. Hence, VGI should be incorporated into a virtual geographic environment to address these issues within the planning and development framework (Figure 4).

\subsection{Conceptual Links between VGI, 3D Spatial Information and Neighbourhood Character}

Some subjective and objective measures overlap. For instance, street activities can be both functional and socially constructed. In addition, while landscape elements in a neighbourhood may be objective, their quality is subjective, and can be considered to be a part of place experience as well as being socially constructed. Figure 5 shows the interaction of the various indicators in a framework with 3D visualisation, 3D nonvisual analysis, VGI, and 3DVGI integrated in a virtual geographic environment.

Figure 5 is an abstraction of the comprehensive range of subjective and objective measurements, and demonstrates their possible interactions in the virtual geographic environment. This framework indicates how spatial technologies would enhance the assessment of subjective and objective measures; in particular, where there are overlaps. For instance, VGI can help identify both the types of physical circumstances that make people fearful and also where they experience these fears in the existing neighbourhood. At the same time, 3D modelling can show the degree of isolation of houses, areas and people from others in a neighbourhood, which is a complementary indicator for safety in planning. Such a model will also allow people to explore proposed buildings and report areas of security concerns (Toet \& van Schaik, 2012).

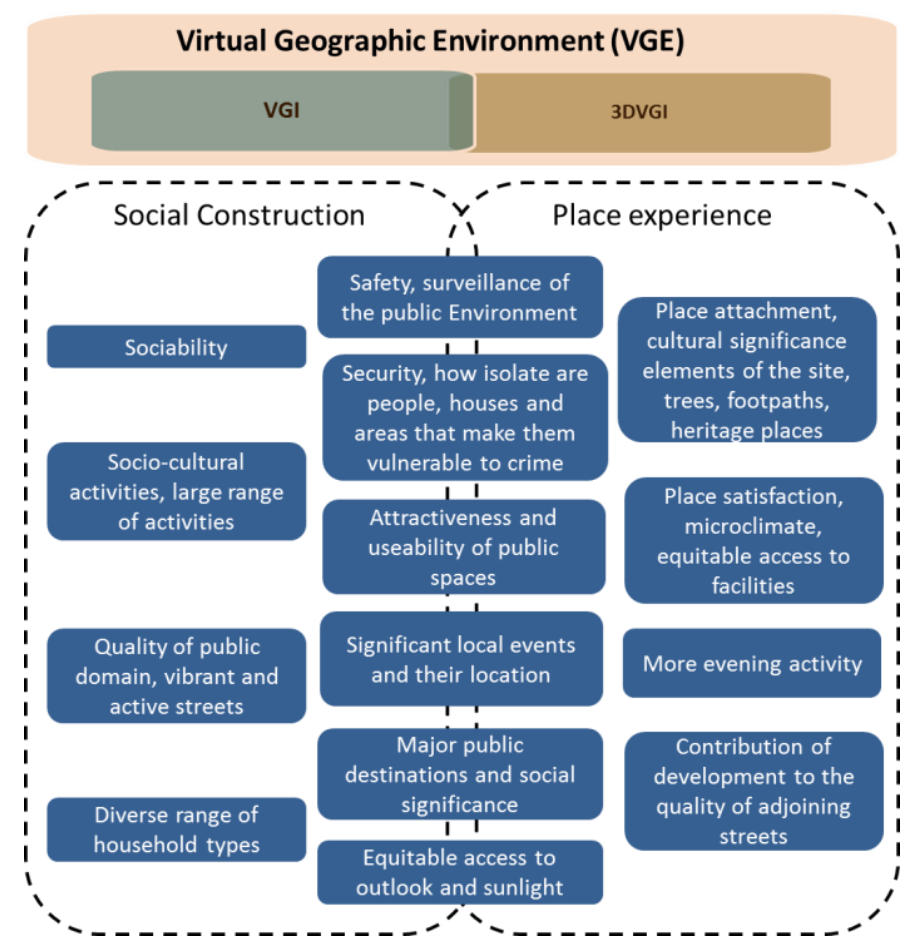

Figure 4. Measuring subjective aspects of building and neighbourhood using VGI and 3 DVGI in a virtual geographic environment. 


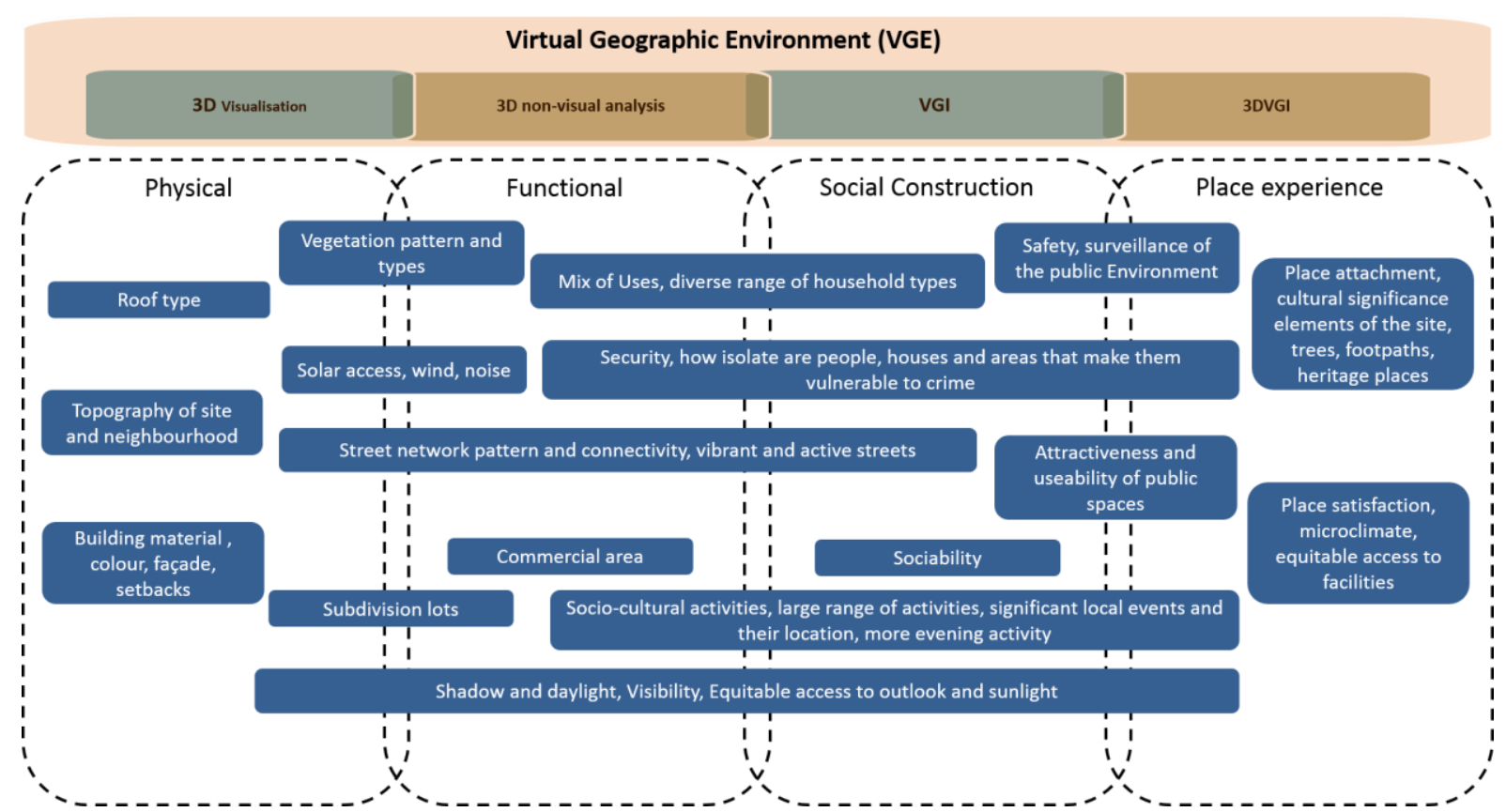

Figure 5. A conceptual framework for incorporating subjective and objective measurements of neighbourhood character in a Virtual Geographic Environment.

There are several advantages that this platform can offer within the requirements of statutory planning regulations:

- The VGE can be considered as a shared environment for all stakeholders-planners, developers and communities - to understand the real impact of developments in an evidencebased and data-driven analysis;

- Given the limited timeframe stipulated by statutory planning regulations, this environment is able to simulate the impacts of single building developments using ongoing data streams from VGI to foster a more rapid decision-making process;

- There is a possibility of generating new analytical methods in this environment by enabling the decision-makers to conduct a holistic analysis. For instance, while shadow analysis is a physical measurement of a building, the socio-behavioural impacts of a shadow cast can also be investigated;

- This platform has the ability to indicate the trajectory of neighbourhood character changes from subjective and objective points of view;

- Based on the ability to generate and store spatial data, the VGE platform is able to foster plan monitoring and strategic planning phases as well.

This is a conceptual framework that needs a proof of concept and implementation in current organisational systems, using available data in Melbourne. As such, developing such a platform in the state and local government planning systems is the next challenge with several concerns addressed in the next section.

\section{Discussion and Conclusion}

The concept of neighbourhood character is one that is entrenched in contemporary planning paradigms and the literature supports an unwavering view that this should constitute physical, social and psychological elements of the lived environment. This however, continues to be weakly translated into planning practices and plan implementation. Objective indicators, reflecting the physical and functional aspects of the urban environment, continue to be the dominant approach to planning assessment and analysis. This is likely due to the relative ease in collecting and measuring performance in these aspects. In recent years, attention has been turning towards the need to understand the types of subjective indicators that can be used to represent measures of neighbourhood character and these tend to cut across socially constructed and experiential aspects.

A review of applications in 3D geospatial technologies, digital geographic environments, and the mainstreaming of geographic data collection activities like VGI indicate clear potential for planning applications. In particular, the nature of VGI holds tremendous promise for collecting information relevant to subjective aspects of neighbourhood character, a mechanism also sensitive to temporal shifts in perceptions. However, it is apparent that to maximise the use of VGI, it is essential that planners and developers are able to clearly define all aspects of neighbourhood character. It therefore becomes necessary to have a comprehensive range of indicators.

Using Victoria's development standards and guidelines, this investigation extracted a comprehensive range 
of micro-level objective and subjective indicators that are important considerations in urban intensification. As indicated in the literature, these indicators resonate in urban redevelopment and intensification projects in other contexts such as Perth, Australia (Davison \& Rowden, 2012) and Helsinki, Finland (Kyttä et al., 2013). We propose a framework that taps into the strengths of 3D spatial information for modelling and analysing objective indicators around physical and functional aspects of the environment. Similarly, VGI (and 3DVGI) is proposed as an appropriate mechanism for collecting information about the socially constructed and experiential aspects of the environment. It is likely that such an integrated approach will promote more effective understanding of communities' perceptions regarding current and future neighbourhood character. The framework is also predicated on a shift from paper-based formats to the use of a virtual geographic environment as a shared platform for communication. Such a dynamic platform for engagement is an effective way to integrate VGI and 3D spatial information. In addition, the nature of digital platforms is such that they can facilitate access more readily to different types of information, which is likely to enable a better quality of public engagement within the constraints of short statutory timeframes.

As this is a conceptual framework, the next step requires implementation of the framework to identify technical and data related issues that might challenge information interoperability, particularly in integrating structured and unstructured data, textual and graphical data, and combining data at different dimensions and scales. Subsequent future research will also need to consider the social implications of embedding this framework within planning and development processes including organisational workflows, regulatory implications and providing a structure to facilitate and normalise community participation through virtual geographic environments.

\section{Acknowledgments}

We thank the two anonymous reviewers for their constructive comments.

\section{Conflict of Interests}

The authors declare no conflict of interests.

\section{References}

Adams, D. (2013). Volunteered geographic information: potential implications for participatory planning. Planning Practice \& Research, 28(4), 464-469.

Aitamurto, T., Leiponen, A., \& Tee, R. (2011). The promise of idea crowdsourcing: Benefits, contexts, limitations. Idea, 1(June), 1-30.

Amirebrahimi, S., Rajabifard, A., Mendis, P., Ngo, T., \&
Sabri, S. (2016). A planning decision support tool for evaluation and $3 d$ visualisation of building risk in flood prone areas. In FIG Working Week 2016: Recover from disaster. Christchurch, New Zealand: FIG.

Biljecki, F., Stoter, J., Ledoux, H., Zlatanova, S., \& Çöltekin, A. (2015). Applications of 3D city models: State of the art review. ISPRS International Journal of GeoInformation, 4(4), 2842-2889. doi:10.3390/ijgi40428 42

Bishop, I. D. (2001). Predicting movement choices in virtual environments. Landscape and Urban Planning, 56(3/4), 97-106. doi:10.1016/S0169-2046(01)001773

Bonaiuto, M., Fornara, F., \& Bonnes, M. (2006). Perceived residential environment quality in middle and low-extension italian cities. Revue Européenne de Psychologie Appliquée/European Review of Applied Psychology, 56(1), 23-34. doi:10.1016/j.erap.2005. 02.011

Bonaiuto, M., Fornara, F., Ariccio, S., Ganucci Cancellieri, U., \& Rahimi, L. (2015). Perceived Residential Environment Quality Indicators (PREQIs) relevance for UN-HABITAT City Prosperity Index (CPI). Habitat International, 45, 53-63. doi:10.1016/j.habitatint.2014. 06.015

Borrmann, A., Kolbe, T. H., Donaubauer, A., Steuer, H., Jubierre, J. R., \& Flurl, M. (2014). Multi-scale geometric-semantic modeling of shield tunnels for GIS and BIM applications. Computer-Aided Civil and Infrastructure Engineering, 30(4), 263-281. doi:10.1111/ mice. 12090

Brabham, D. C. (2009). Crowdsourcing the public participation process for planning projects. Planning Theory, 8(3), 242-262. doi:10.1177/1473095209104824

Brownson, R. C., Hoehner, C. M., Day, K., Forsyth, A., \& Sallis, J. F. (2009). Measuring the built environment for physical activity: State of the science. American Journal of Preventive Medicine, 36(4 Suppl), S99S123.e12. doi:10.1016/j.amepre.2009.01.005

Budhathoki, N. R., Nedovic-Budic, Z., \& Bruce, B. (2010). An interdisciplinary frame for understanding volunteered geographic information. Geomatica, 64(1), 11-26.

Campagna, M., Floris, R., Massa, P., Girsheva, A., \& Ivanov, K. (2015). The Role of Social Media Geographic Information (SMGI) in spatial planning. In S. Geertman, J. Ferreira Jr., R. Goodspeed, \& J. Stillwell (Eds.), Planning support systems and smart cities (pp. 4160). Cham: Springer International Publishing. doi:10.1007/978-3-319-18368-8_3

Chang, T. C. (2000). Singapore's Little India: A tourist attraction as a contested landscape. Urban Studies, 37(2), 343-366. doi:10.1080/0042098002221

Chen, Y., \& Bishop, I. D. (2011). Simulating visitors recreational activities in a virtual environment. In Modelling and simulation (pp. 161-167). Calgary, Canada: ACTAPRESS. doi:10.2316/P.2011.735-017 
Chen, L., Ng, E., An, X., Ren, C., Lee, M., Wang, U., \& He, Z. (2012). Sky view factor analysis of street canyons and its implications for daytime intra-urban air temperature differentials in high-rise, high-density urban areas of Hong Kong: a GIS-based simulation approach. International Journal of Climatology, 32(1), 121-136. doi:10.1002/joc.2243

D’Argent, N. M. J., Beringer, J., Tapper, N., \& Coutts, A. (2012). Planning for the compact city: An assessment of melbourne@5 million. In WSUD 2012:7th International Conference on Water Sensitive Urban Design: Building the water sensitive community. Retrieved from http://www.scopus.com/inward/record.url?eid $=2-s 2.0-84862013838 \&$ partnerID=tZOtx3y1

Davison, G. (2011). An unlikely urban symbiosis: Urban intensification and neighbourhood character in Collingwood, Vancouver. Urban Policy and Research, 29(2), 105-124. doi:10.1080/08111146.2011.557995

Davison, G., \& Rowden, E. (2012). “There's something about Subi": Defending and creating neighbourhood character in Perth, Australia. Journal of Urban Design, 17(2), 189-212. doi:10.1080/13574809.2012. 666386

de Jong, U., Fuller, R., \& Gray, F. (2013). From fibro shacks to McMansions: Considering the impact of housing change on the sense of place in the historic Victorian coastal towns of Sorrento and Queenscliff. In AHRC 2013 : 7th Australasian Housing Researchers' Conference: Housing the Needs of Diverse Populations, 1-18. Retrieved from http://dro.deakin.edu. au/view/DU:30060738

Department of Sustainability and Environment. (2004). Guidelines for higher density residential development. Melbourne: Department of Sustainability and Environment. Retrieved from http://www.dtpli.vic. gov.au/planning/urban-design-and-development/ur ban-design-guidelines/higher-density-residential-dev elopment

Dovey, K., \& Wood, S. (2014). Public/private urban interfaces: Type, adaptation, assemblage. Journal of Urbanism: International Research on Placemaking and Urban Sustainability, 8(1), 1-16. doi:10.1080/17549 175.2014.891151

Dovey, K., \& Woodcock, I. (2011). The character of urban intensification: A report on research projects funded by the Australian Research Council, 2002-2010. Melbourne: University of Melbourne. Retrieved from http://msd.unimelb.edu.au/sites/default/files/docs/ The_Character_of_Urban_Intensification_2011.pdf

Dovey, K., Woodcock, I., \& Wood, S. (2009a). A test of character: Regulating place-identity in Inner-city Melbourne. Urban Studies, 46(12), 2595-2615. doi:10.1177/0042098009344229

Dovey, K., Woodcock, I., \& Wood, S. (2009b). Understanding neighbourhood character: The case of Camberwell. Australian Planner, 46(3), 32-39. doi:10.1080/07293682.2009.10753406
Elmadhoun Ahmed, M. A. (2010). Using neogeography technology to support participatory spatial planning. ITC. Retrieved from http://Inweb90.worldbank.org/ exteu/SharePapers.nsf/(ID)/B332869518DFD06D852 577B800216DFC/\$File/gfm-ahmed+madhoun-17579 .pdf

Elwood, S. (2008). Volunteered geographic information: Future research directions motivated by critical, participatory, and feminist GIS. GeoJournal, 72(3), 173183. doi:10.1007/s10708-008-9186-0

Elwood, S., \& Leitner, H. (2003). Community-based planning and GIS: Aligning neighbourhood organizations with state priorities? Journal of Urban Affairs, 25, 139-157.

Ertiö, T. (2013). M-participation: The emergence of participatory planning applications. Research Briefings 6b/2013. Retrieved from http://www.turkuai.fi/sit es/default/files/atoms/files/tutkimuskatsauksia_201 3-6b.pdf

Ertiö, T.-P. (2015). Participatory apps for urban planning: Space for improvement. Planning Practice \& Research, 30(3), 303-321.

Evans-Cowley, J., \& Hollander, J. (2010). The new generation of public participation: Internet-based participation tools. Planning, Practice \& Research. Retrieved from http://www.tandfonline.com/doi/abs/ 10.1080/02697459.2010.503432\#.V05Lq4R95hE

Ewing, R., Hajrasouliha, A., Neckerman, K. M., PurcielHill, M., \& Greene, W. (2015). Streetscape features related to pedestrian activity. Journal of Planning Education and Research, 36(1), 5-15. doi:10.1177/ $0739456 \times 15591585$

Fenton, M. (2012). Community design and policies for free-range children: Creating environments that support routine physical activity. Childhood Obesity, 8(1), 44-51. Retrieved from http://www.ncbi.nlm. nih.gov/pubmed/22799480

Fleury-Bahi, G., Félonneau, M.-L., \& Marchand, D. (2008). Processes of place identification and residential satisfaction. Environment and Behavior, 40(5), 669-682. doi:10.1177/0013916507307461

Foth, M., Bajracharya, B., Brown, R. A., \& Hearn, G. N. (2009). The Second Life of urban planning? Using neogeography tools for community engagement. Journal of Location Based Services, 3(2), 97-117.

Foth, M., Odendaal, N., \& Hearn, G. N. (2007). The view from everywhere: Towards an epistemology for urbanites. In D. Remenyi (Ed.), Proceedings of the 4th International Conference on Intellectual Capital, Knowledge Management and Organizational Learning (ICICKM) (Vol. 127, pp. 127-133). Sonning Common, UK: Academic Conferences. Retrieved from http://eprints.qut.edu.au/9149

Gilmour, T. (2012). Overcoming NIMBY opposition to developing new affordable housing (Kinetic White $\mathrm{Pa}$ per Series 4, No. 4). Retrieved from http://www. housingaction.net.au/sites/default/files/research/ni 
mby_opposition.pdf

Glaesener, M.-L., \& Caruso, G. (2015). Neighborhood green and services diversity effects on land prices: Evidence from a multilevel hedonic analysis in Luxembourg. Landscape and Urban Planning, 143, 100111. doi:10.1016/j.landurbplan.2015.06.008

Goetz, M., \& Zipf, A. (2013). The evolution of geocrowdsourcing: Bringing volunteered geographic information to the third dimension. In D. Sui, S. Elwood, \& M. Goodchild (Eds.), Crowdsourcing geographic knowledge (pp. 139-159). Dordrecht: Springer. doi:10.1007/978-94-007-4587-2_9

Goodchild, M. F. (2007). Citizens as sensors: The world of volunteered geography. GeoJournal, 69(4), 211-221. doi:10.1007/s10708-007-9111-y

Green, R. (1999). Meaning and form in community perception of town character. Journal of Environmental Psychology, 19(4), 311-329. doi:10.1006/jevp.1999. 0143

Green, R. J. (2010). Coastal towns in transition: Local perceptions of landscape change. Dordrecht: Springer. doi:10.1007/978-1-4020-6887-4

Gröger, G., \& Plümer, L. (2012). CityGML: Interoperable semantic 3D city models. ISPRS Journal of Photogrammetry and Remote Sensing, 71, 12-33. doi:10.1016/j.isprsjprs.2012.04.004

Hague, C. (2005). Planning and place identity. In C. Hague \& P. Jenkins (Eds.), Place identity, participation and planning (Vol. 7, pp. 3-18). London, UK: Routledge.

Haklay, M. (2013). Citizen science and volunteered geographic information: Overview and typology of participation. In D. Sui, S. Elwood, \& M. Goodchild (Eds.), Crowdsourcing geographic knowledge (pp. 105-122). Dordrecht: Springer. doi:10.1007/978-94-007-45872_7

Harvey, C., \& Aultman-Hall, L. (2015). Measuring urban streetscapes for livability: A review of approaches. The Professional Geographer, 68(1), 149-158. doi:10.1080/00330124.2015.1065546

Harvey, C., Aultman-Hall, L., Hurley, S. E., \& Troy, A. (2015). Effects of skeletal streetscape design on perceived safety. Landscape and Urban Planning, 142, 18-28. doi:10.1016/j.landurbplan.2015.05.007

Hassett, D. (2014). City of Melbourne. Melbourne: The University of Melbourne.

Herman, L., \& Rezník, T. (2013). Web 3D visualization of noise mapping for extended INSPIRE buildings model. In J. Hřebíček, G. Schimak, M. Kubásek, \& A. Rizzoli (Eds.), Environmental software systems. Fostering information sharing (Vol. 413, pp. 414-424). Berlin: Springer. doi:10.1007/978-3-642-41151-9_39

Houghton, K., Miller, E., \& Foth, M. (2014). Integrating ICT into the planning process: Impacts, opportunities and challenges. Australian Planner, 51(1), 24-33. doi:10.1080/07293682.2013.770771

Hunter, M. C. R., \& Brown, D. G. (2012). Spatial conta- gion: Gardening along the street in residential neighborhoods. Landscape and Urban Planning, 105(4), 407-416. doi:10.1016/j.landurbplan.2012.01.013

Jean, S. (2015). Neighbourhood attachment revisited: Middle-class families in the Montreal metropolitan region. Urban Studies. doi:10.1177/004209801559 4089

Jiang, B. (2013). Volunteered geographic information and computational geography: New perspectives. In D. Sui, S. Elwood, \& M. Goodchild (Eds.), Crowdsourcing geographic knowledge: volunteered geographic information (VGI) in theory and practice (pp. 125138). Dordrecht: Springer. doi:10.1007/978-94-0074587-2_8

Jive'n, G., \& Larkham, P. J. (2003). Sense of place, authenticity and character: A commentary. Journal of Urban Design, 8(1), 67-81. doi:10.1080/135748003 2000064773

Knudsen, A.-M. S., \& Kahila, M. (2012, April 11). The role of volunteered geographic information in participatory planning. Examples from Denmark and Finland. Geoforum Perspektiv. doi:10.5278/ojs.persk..v11i21. 488

Kolbe, T., Gröger, G., \& Plümer, L. (2005). CityGML: Interoperable access to $3 \mathrm{D}$ city models. In $\mathrm{P}$. van Oosterom, S. Zlatanova, \& E. Fendel (Eds.), Geoinformation for disaster management (pp. 883-899). Berlin: Springer. doi:10.1007/3-540-27468-5_63

Kolbitsch, J., \& Maurer, H. (2006). The transformation of the web: How emerging communities shape the information we consume. Journal of Universal Computer Science, 12(2), 187-213. doi:10.3217/jucs-01202-0187

Kropf, K. (1996). Urban tissue and the character of towns. Urban Design International, 1(3), 247-263. doi:10.1057/udi.1996.32

Kyle, G., \& Chick, G. (2007). The social construction of a sense of place. Leisure Sciences, 29(3), 209-225. doi:10.1080/01490400701257922

Kytta, M., Broberg, A., Haybatollahi, M., \& SchmidtThome, K. (2015). Urban happiness: Contextsensitive study of the social sustainability of urban settings. Environment and Planning B: Planning and Design, 43(1), 34-57. doi:10.1177/0265813515600121

Kyttä, M., Broberg, A., Tzoulas, T., \& Snabb, K. (2013). Towards contextually sensitive urban densification: Location-based softGIS knowledge revealing perceived residential environmental quality. Landscape and Urban Planning, 113, 30-46. doi:10.1016/j.land urbplan.2013.01.008

Larco, N. (2015). Sustainable urban design: A (draft) framework. Journal of Urban Design, 21(1), 1-29. doi:10.1080/13574809.2015.1071649

Leimeister, J. M., Huber, M., Bretschneider, U., \& Krcmar, H. (2009). Leveraging crowdsourcing: activation-supporting components for IT-based ideas competition. Journal of Management Information Sys- 
tems, 26(1), 197-224. doi:10.2753/MIS0742-1222260 108

Lin, H., Chen, M., Lu, G., Zhu, Q., Gong, J., You, X., . . Hu, M. (2013). Virtual geographic environments (VGEs): A new generation of geographic analysis tool. EarthScience Reviews, 126, 74-84. doi:10.1016/j.earsci rev.2013.08.001

Meehan, P. J. (1982). Urban design criteria for small town central business districts: Midwest USA. Ekistics. Retrieved from http://www.scopus.com/inwa rd/record.url?eid=2-s2.0-0020450384\&partnerID=tZ Otx3y1

Mignard, C., \& Nicolle, C. (2014). Merging BIM and GIS using ontologies application to urban facility management in ACTIVe3D. Computers in Industry, 65(9), 1276-1290. doi:10.1016/j.compind.2014.07.008

Montgomery, J. (1998). Making a city: Urbanity, vitality and urban design. Journal of Urban Design, 3(1), 93116. doi:10.1080/13574809808724418

Nikšič, M., Tominc, B., Goršič, N., Mladenovič, L., Marušić, B. G., \& Bizjak, I. (2014). Practices to collect VGI for the aims of better city planning. In COST Action TD 1202: Mapping and the Citizen Sensor. Vienna, 22-23 September 2014. Retrieved from http://www.citizensensor-cost.eu/wp-content/uploa ds/2014/10/MatejNiksic.pdf

Obermeyer, N. (2007). Thoughts on volunteered (geo)slavery. Applied geography. Retrieved from http://www.ncgia.ucsb.edu/projects/vgi/docs/positi on/Obermeyer\{_\}Paper.pdf

Porta, S., \& Renne, J. L. (2005, March 30). Linking urban design to sustainability: Formal indicators of social urban sustainability field research in Perth, Western Australia. Urban Design International. Retrieved from http://strathprints.strath.ac.uk/18461/1/strathprints 018461.pdf

Psyllidis, A., Bozzon, A., Bocconi, S., \& Titos Bolivar, C. (2015). A platform for urban analytics and semantic data integration in city planning. In G. Celani, D. M. Sperling, \& J. M. Franco (Eds.), Computer-aided architectural design futures. The next city: New technologies and the future of the built environment (Vol. 527, pp. 21-36). Berlin: Springer. doi:10.1007/978-3662-47386-3_2

Purciel, M., Neckerman, K. M., Lovasi, G. S., Quinn, J. W., Weiss, C., Bader, M. D. M., . . . Rundle, A. (2009). Creating and validating GIS measures of urban design for health research. Journal of Environmental Psychology, 29(4), 457-466. doi:10.1016/j.jenvp.2009. 03.004

Qin, J., Zhou, X., Sun, C., Leng, H., \& Lian, Z. (2013). Influence of green spaces on environmental satisfaction and physiological status of urban residents. Urban Forestry \& Urban Greening, 12(4), 490-497. doi:10.1016/j.ufug.2013.05.005

Rafiee, A., Dias, E., Fruijtier, S., \& Scholten, H. (2014). From BIM to geo-analysis: View coverage and shad- ow analysis by BIM/GIS integration. Procedia Environmental Sciences, 22, 397-402. doi:10.1016/j. proenv.2014.11.037

Relph, E. (1976). Place and placelessness. London, UK: Pion.

Rydin, Y. (2010). The purpose of planning. London, UK: Policy Press.

Sabri, S., Pettit, C. J., Bishop, I. D., \& Rajabifard, A. (2015). Challenges for integrating subjective and objective measures in urban quality of life appraisal for future smart living. In Open Cities, Open Data Workshop, Sydney.

Sabri, S., Pettit, C. J., Kalantari, M., Rajabifard, A., White, M., Lade, O., \& Ngo, T. (2015). What are essential requirements in planning for future cities using open data infrastructures and $3 \mathrm{~d}$ data models? In 14th Computers in urban planning and urban management (CUPUM2015) (pp. 314-1-314-17). Boston, MA: MIT. Retrieved from http://web.mit.edu/cron/ project/CUPUM2015/proceedings/Content/pss/314 _sabri_h.pdf

Samuels, R. (2002). Perennial old-city paradigms. In Advances in architecture series (Vol. 14, pp. 693-703). Retrieved from http://www.scopus.com/inward/rec ord.url?eid=2-s2.0-3342966897\&partnerID=tZOtx3y1

Schmidt-Thome, K., Wallin, S., Laatikainen, T., Kangasoja, J., \& Kyttä, M. (2014). Exploring the use of PPGIS in self-organizing urban development: Case softGIS in Pacific Beach. The Journal of Community Informatics, 10(3).

Schwartz, L., Dodd, A., \& Haley, K. (2014). Tribunal tension: Coming to a suburb near you. Retrieved from http://www.theage.com.au/victoria/tribunal-tension-coming-to-a-suburb-near-you-20140111-30nu1.html

Schwarz, N. (2010). Urban form revisited: Selecting indicators for characterising European cities. Landscape and Urban Planning, 96(1), 29-47. doi:10.1016/j.land urbplan.2010.01.007

Seltzer, E., \& Mahmoudi, D. (2013). Citizen participation, open innovation, and crowdsourcing: challenges and opportunities for planning. Journal of Planning Literature, 28(1), 3-18. doi:10.1177/0885412212469112

Sepe, M., \& Pitt, M. (2014). The characters of place in urban design. Urban Design International, 19(3), 215227. doi:10.1057/udi.2013.32

Shojaei, D., Rajabifard, A., Kalantari, M., Bishop, I. D., \& Aien, A. (2014). Design and development of a webbased 3D cadastral visualisation prototype. International Journal of Digital Earth, 1-20. doi:10.1080/17538947.2014.902512

Sieber, R. (2006). Public participation geographic information systems: A literature review and framework. Annals of the Association of American Geographers, 96(3), 491-507. doi:10.1111/j.1467-8306.2006.007 $02 . x$

Smith, D. P., \& Phillips, D. A. (2001). Socio-cultural representations of gentrified Pennine rurality. Journal of 
Rural Studies, 17(4), 457-469. doi:10.1016/S07430167(01)00014-6

Smith, E. L., Bishop, I. D., Williams, K. J. H., \& Ford, R. M. (2012). Scenario chooser: An interactive approach to eliciting public landscape preferences. Landscape and Urban Planning, 106(3), 230-243. doi:10.10 16/j.landurbplan.2012.03.013

Song, W., \& Sun, G. (2010). The role of mobile volunteered geographic information in urban management. In 2010 18th International Conference on Geoinformatics (pp. 1-5). Washington, DC: IEEE. doi:10.1109/GEOINFORMATICS.2010.5567728

Stedman, R. C. (2003). Is it really just a social construction? The contribution of the physical environment to sense of place. Society \& Natural Resources, 16(8), 671-685. doi:10.1080/08941920309189

Stock, C., Bishop, I. D., \& Green, R. (2007). Exploring landscape changes using an envisioning system in rural community workshops. Landscape and Urban Planning, 79(3/4), 229-239. doi:10.1016/j.landurb plan.2006.02.010

Strzalka, A., Bogdahn, J., Coors, V., \& Eicker, U. (2011). 3D City modeling for urban scale heating energy demand forecasting. HVAC\&R Research, 17(4), 526-539. doi:10.1080/10789669.2011.582920

Toet, A., \& van Schaik, M. G. (2012). Effects of signals of disorder on fear of crime in real and virtual environments. Journal of Environmental Psychology, 32(3), 260-276. doi:10.1016/j.jenvp.2012.04.001

Trubka, R., Glackin, S., Lade, O., \& Pettit, C. (2015). A web-based $3 \mathrm{D}$ visualisation and assessment system for urban precinct scenario modelling. ISPRS Journal of Photogrammetry and Remote Sensing. doi:10. 1016/j.isprsjprs.2015.12.003

Vallance, S., Perkins, H. C., \& Moore, K. (2005). The results of making a city more compact: Neighbours' interpretation of urban infill. Environment and Planning B: Planning and Design, 32(5), 715-733.

Verburg, P. H., de Nijs, T. C. M., van Eck, J. R., Visser, H., $\&$ de Jong, K. (2004). A method to analyse neighborhood characteristics of land use patterns. Computers, Environment and Urban Systems, 28, 667-690.

Victoria Government. (2014). PlanMelbourne metropolitan planning strategy. Melbourne: Victoria Government.

Victoria Government, D. (2015). Planning practice note 43: Understanding neighbourhood character. The
State of Victoria Department of Environment, Land, Water and Planning. Retrieved from http://www. dtpli.vic.gov.au/planning/planning-publications/pra ctice-and-advisory-notes/practice-notes-master-list/ ppn43-understanding-neighbourhood-character

Walker, R. E., Block, J., \& Kawachi, I. (2013). The spatial accessibility of fast food restaurants and convenience stores in relation to neighborhood schools. Applied Spatial Analysis and Policy, 7(2), 169-182. doi:10.1007/s12061-013-9095-6

Walton, D., Murray, S. J., \& Thomas, J. A. (2008). Relationships between population density and the perceived quality of neighbourhood. Social Indicators Research, 89(3), 405-420. doi:10.1007/s11205-0089240-9

Weiner, D., Harris, T. M., \& Craig, W. J. (2002). Community participation and geographic information systems. Society, 1-18. doi:10.1201/9780203469484

Woodcock, I., Dovey, K., \& Davison, G. (2012). Envisioning the compact city: Resident responses to urban design imagery. Australian Planner, 49(1), 65-78. doi:10.1080/07293682.2011.595726

Woodcock, I., Dovey, K., Wollan, S., \& Beyerle, A. (2010). Modelling the compact city: Capacities and visions for Melbourne. Australian Planner, 47(2), 94-104. doi:10.1080/07293681003767793

Xiao, Y., Orford, S., \& Webster, C. J. (2015). Urban configuration, accessibility, and property prices: A case study of Cardiff, Wales. Environment and Planning B: Planning and Design, 43(1), 108-129. doi:10.1177/ 0265813515600120

Zhang, C., Chen, M., Li, R., Fang, C., \& Lin, H. (2016). What's going on about geo-process modeling in virtual geographic environments (VGEs). Ecological Modelling, 319, 147-154. doi:10.1016/j.ecolmodel. 2015.04.023

Zheng, Y.-T., Zha, Z.-J., \& Chua, T.-S. (2011). Research and applications on georeferenced multimedia: a survey. Multimedia Tools and Applications, 51(1), 77-98. doi:10.1007/s11042-010-0630-z

Zhu, Q., Zhao, J., Du, Z., Zhang, Y., Xu, W., Xie, X. . . . Wang, T. (2011). Towards semantic 3D city modeling and visual explorations. In T. H. Kolbe, G. König, \& C. Nagel (Eds.), Advances in 3D geo-information sciences (pp. 275-294). Springer Berlin Heidelberg. doi:10.1007/978-3-642-12670-3_17

\section{About the Authors}

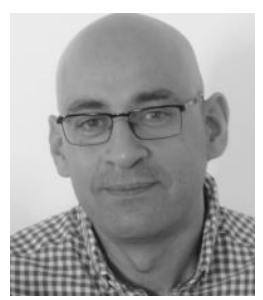

Soheil Sabri is an Urban Planner and Postdoctoral Research Fellow in Urban Analytics at the Centre for SDIs and Land Administration in The University of Melbourne. His research focuses on enabling spatial information and technological innovation in smart urban planning and design to improve urban quality of life. 

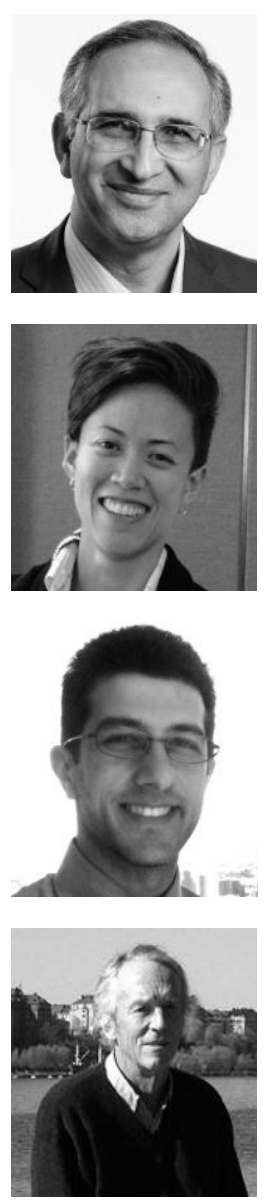

Abbas Rajabifard is Head of the Department of Infrastructure Engineering and Director of both the Centre for SDls and Land Administration and the Centre for Disaster Management and Public Safety, in the University of Melbourne. He is immediate Past-President of Global SDI (GSDI) Association and is an Executive Board member of this Association. Abbas was Vice Chair, Spatially Enabled Government Working Group of the UN Global Geospatial Information Management for Asia and the Pacific.

Serene Ho is a Postdoctoral Research Fellow on 3D Land and Property Information at the Centre for SDIs and Land Administration, in The University of Melbourne. Her research focuses on the institutional (social, cultural, organisational and regulatory) aspects of technological innovation in land administration and the spatial sciences.

Sam Amirebrahimi is a spatial data scientist with the Centre for Spatial Data Infrastructures and Land Administration in the University of Melbourne. With extensive experience in software development industry and in-depth training in GIS systems, Sam's focus is mainly on the use of state-of-the-art technologies for conceptualisation and implementation of multidisciplinary projects in the areas of engineering, urban informatics, cadastre, and disaster management.

Ian Bishop is an honorary Professorial Fellow in the Department of Infrastructure Engineering, School of Engineering at The University of Melbourne. He also works as a consultant on aspects of spatial information management and visualisation through the Cooperative Research Centre for Spatial Information. His research interest is a wide range of computer applications in environmental assessment, planning and design. 